\title{
Effect of dietary protein on performance of four broiler strains and on the allometric relationships between carcass portions and body protein
}

\author{
R. Danisman \& R.M. Gous \\ Animal and Poultry Science, University of KwaZulu-Natal, Pietermaritzburg, South Africa \\ (Received 18 May 2012; Accepted 15 January 2013; First published online 9 March 2013)
}

Copyright resides with the authors in terms of the Creative Commons Attribution 2.5 South African Licence.

See: http://creativecommons.org/licenses/by/2.5/za

Condition of use: The user may copy, distribute, transmit and adapt the work, but must recognise the authors and the South African Journal of Animal Science.

\begin{abstract}
This is the second paper in a series that reports the allometric relationships between some of the physical parts and body protein weight of commercial broiler strains reared, sexes separate, on different dietary protein levels. In this trial, four commercial broiler strains were sampled at day old and then weekly from each of three dietary protein treatments to determine the weights of the physical parts and the chemical composition of each of 936 birds. Allometric regressions were compared between strains, sexes and dietary protein levels using linear regression with groups. Whereas these regressions were similar over strains and sexes, some interactions were evident between factors, the largest differences occurring when broilers were fed differing dietary protein levels. These differences may be explained on the basis that lipid is deposited to different extents in each of the parts in response to dietary protein. Day-old breast meat and wing weights fell below the regression that best fitted the remaining observations and so were omitted from allometric analyses. The allometric regressions presented are an attempt to provide information that would enable the prediction of the weights of breast meat, thigh, drum and wing at different stages of growth of broilers whose genotype and feed composition are adequately described.
\end{abstract}

Keywords: Breast meat, thigh, drum, wing, carcass yield

" Corresponding author: gous@ukzn.ac.za

\section{Introduction}

In an earlier paper (Danisman \& Gous, 2011) comparisons were made of the allometric relationships between some of the physical parts and body protein weight of three commercial broiler strains reared, sexes separate, on four dietary protein levels to six weeks of age. The allometric regressions presented were an attempt to provide information that would enable the prediction of the weights of breast meat, thigh, drum and wing at different stages of growth of broilers whose genotype and feed composition are adequately described. The most important finding from that trial was that, although the allometric regressions differed marginally according to the dietary protein level fed, there were no differences between strains or sexes. This is contrary to the many reports claiming that improvements have been made in the yield of parts (breast meat in particular) of broilers, with resultant 'high yield' strains having been developed by some breeding companies (Cobb, 2007; Aviagen, 2009). These claims are made by comparing strains at an age or at a body weight, but not at a protein weight. Where this latter has been used for comparative purposes, even when there are large differences in the growth rates and mature body weights between strains and sexes the allometric relationships have not differed (Gous et al., 1996).

The objective of the present trial was to gather further evidence of the apparent lack of differences in the allometric relationships between body protein weight and the weights of breast meat, thigh, drum and wing between strains and sexes, thereby corroborating the evidence from previous trials. In this trial the same relationships were again measured using a fourth strain in addition to the three strains used previously. 


\section{Materials and Methods}

Four strains of commercial broiler available in South Africa, namely Ross 788, Ross 308, Cobb 500 and Hybro, were obtained from local hatcheries, sexed, and placed at dayold in a controlled environmental broiler facility on the University of KwaZulu-Natal research farm. The genetic characteristics of these four strains are described in Hancock et al. (1995). Each of 48 floor pens was populated with 64 chickens, with males and females being reared separately, i.e. six pens of males and six of females of each of four strains were used in the trial. The trial was terminated when the birds were $84 \mathrm{~d}$ old as a means of obtaining as wide a range of body protein and component weights as possible for purposes of fitting allometric curves.

Two basal starter feeds, one high and the other low in protein (Table 1) were the same as those used in the previous trial except that they were blended $(50: 50)$ to produce only one additional level of protein. Amino acid specifications used in the basal feeds were approximately 1.2 and 0.75 of those recommended by Aviagen (2009) for broilers. The two basal feeds were sampled after mixing and these were analysed for apparent metabolisable energy (AME) using the method of Fisher \& McNab (1989) and digestible amino acid content using a Waters amino acid analyser (AOAC, 2003). Feed and water were offered ad libitum throughout the trial. The starter feeds were crumbled and offered for the first three weeks whereafter three finisher feeds (Table 1), also of the same composition as those used previously, and blended as described above, were fed as pellets for the remaining nine weeks of the trial.

Table 1 Ingredient and nutrient composition (g/kg) of the low (LP) and high protein (HP) basal starter and finisher feeds used

\begin{tabular}{|c|c|c|c|c|}
\hline \multirow{2}{*}{ Ingredient } & \multicolumn{2}{|c|}{ Starter } & \multicolumn{2}{|c|}{ Finisher } \\
\hline & LP & HP & LP & HP \\
\hline Maize & 532 & 405 & 630 & 485 \\
\hline Soybean full fat & 266 & 470 & 265 & 381 \\
\hline Soybean 480 g CP/kg & 127 & & & \\
\hline Sunflower 370 g CP $/ \mathrm{kg}$ & & 334 & & 228 \\
\hline Fish meal 650 g CP/kg & & 555 & & \\
\hline Limestone & 169 & 124 & 176 & 169 \\
\hline L-lysine $\mathrm{HCl}$ & 0.1 & 0.5 & 0.5 & 0.9 \\
\hline DL methionine & 1.7 & 3.4 & 1.3 & 2.7 \\
\hline L-threonine & & 0.6 & & 0.4 \\
\hline Vit+min premix & 2.5 & 2.5 & 2.5 & 2.5 \\
\hline Choline chloride 60 & 0.7 & & 7.6 & 12.9 \\
\hline Salt & 3 & 2 & 14 & \\
\hline Monocalcium phosphate & 16.6 & 11.6 & 16.8 & 16.6 \\
\hline Sodium bicarbonate & 3 & 2.5 & 6.7 & 8.4 \\
\hline Oil - Soya & 30 & & 50 & 50 \\
\hline \multicolumn{5}{|c|}{ Chemical composition - determined } \\
\hline AME $(\mathrm{MJ} / \mathrm{kg})$ & 13.2 & 13.3 & 13.4 & 13.6 \\
\hline Crude protein & 207 & 261 & 153 & 194 \\
\hline Lysine $^{1}$ & 10.2 & 14 & 7.4 & 10.1 \\
\hline Methionine ${ }^{1}$ & 4.5 & 7.2 & 3.5 & 5.3 \\
\hline Methionine $\&$ cysteine ${ }^{1}$ & 7.4 & 10.3 & 5.8 & 7.9 \\
\hline Threonine $^{1}$ & 6.8 & 9.2 & 5.0 & 6.7 \\
\hline
\end{tabular}


A representative sample (0.5) of birds in each pen was weighed at weekly intervals up to $84 \mathrm{~d}$. Feed allocated to each pen was weighed and transferred to the feeding troughs when necessary. At the end of each week feed remaining in the troughs and in the bag was weighed, to determine the amount of feed consumed during the week. Feed conversion efficiency (FCE) was calculated as g gain $/ \mathrm{kg}$ food consumed.

At day old, six birds were sampled from each strain $\mathrm{x}$ sex, the parts were dissected and weighed, then the chicks from each strain and sex were combined for chemical analysis. Thereafter, two birds were removed from each pen for carcass analysis each week up to the 6th week, and then at 8, 10 and 12 weeks. These birds were treated as described by Danisman \& Gous (2011). The natural log (ln) of the weight of breast, thigh, drum and wing was calculated from which the allometric relationships between these components $(\mathrm{Y})$ and $\ln$ body protein weight $(\mathrm{X})$ were determined using the equation $\ln \mathrm{Y}=\ln \mathrm{a}+\mathrm{b} \ln \mathrm{X}$. The exponent $b$ represents the slope of the linear regression obtained in a logarithmic plot.

In summary, a factorial design was used, with four strains, three protein levels and two sexes. Two replications of each treatment combination were used. Data were subjected to the same statistical analyses as those described by Danisman \& Gous (2011).

\section{Results}

Table 2 Mean body weight $(\mathrm{kg})$ and body lipid content $(\mathrm{g} / \mathrm{kg})$ of males and females of four strains of broiler fed three levels of balanced protein at, and cumulative food intake (kg) to six and 12 weeks of age

\begin{tabular}{|c|c|c|c|c|c|c|c|c|c|c|c|c|}
\hline & \multicolumn{6}{|c|}{$42 \mathrm{~d}$} & \multicolumn{6}{|c|}{$84 \mathrm{~d}$} \\
\hline & \multicolumn{2}{|c|}{ High protein } & \multicolumn{2}{|c|}{ Med. protein } & \multicolumn{2}{|c|}{ Low protein } & \multicolumn{2}{|c|}{ High protein } & \multicolumn{2}{|c|}{ Med. protein } & \multicolumn{2}{|c|}{ Low protein } \\
\hline & $\mathrm{F}^{1}$ & $\mathrm{M}^{2}$ & $\mathrm{~F}$ & M & $\mathrm{F}$ & M & $\mathrm{F}$ & M & $\mathrm{F}$ & M & $\mathrm{F}$ & M \\
\hline & \multicolumn{12}{|c|}{ Body weight (kg) } \\
\hline R308 & 2.51 & 2.96 & 2.32 & 2.75 & 2.39 & 2.59 & 4.70 & 6.36 & 4.82 & 6.25 & 4.92 & 5.95 \\
\hline R788 & 2.43 & 2.83 & 2.32 & 2.68 & 2.30 & 2.68 & 4.96 & 6.28 & 4.94 & 6.11 & 5.12 & 6.38 \\
\hline Cobb & 2.50 & 2.96 & 2.41 & 2.73 & 2.37 & 2.75 & 5.06 & 6.02 & 4.84 & 5.90 & 5.01 & 6.22 \\
\hline Hybro & 2.40 & 2.94 & 2.37 & 2.82 & 2.31 & 2.67 & 5.18 & 6.66 & 5.09 & 6.37 & 5.01 & 6.36 \\
\hline Mean & \multirow{2}{*}{\multicolumn{2}{|c|}{2.69}} & \multicolumn{2}{|c|}{2.55} & \multirow{2}{*}{\multicolumn{2}{|c|}{2.51}} & \multirow{2}{*}{\multicolumn{2}{|c|}{5.65}} & \multicolumn{2}{|c|}{5.54} & \multirow{2}{*}{\multicolumn{2}{|c|}{5.62}} \\
\hline \multirow[t]{2}{*}{$\mathrm{RMS}^{3}$} & & & \multicolumn{2}{|c|}{5.53} & & & & & \multicolumn{2}{|c|}{84.1} & & \\
\hline & \multicolumn{12}{|c|}{ Food intake (kg) } \\
\hline R308 & 4.32 & 4.97 & 4.13 & 4.71 & 4.32 & 4.60 & 13.0 & 16.5 & 13.6 & 16.0 & 13.6 & 15.2 \\
\hline R788 & 4.29 & 4.83 & 4.02 & 4.62 & 4.17 & 4.65 & 14.1 & 16.2 & 13.6 & 16.2 & 13.3 & 15.8 \\
\hline Cobb & 4.10 & 4.59 & 3.92 & 4.45 & 4.03 & 4.69 & 12.5 & 14.1 & 12.1 & 14.3 & 12.4 & 14.5 \\
\hline Hybro & 3.80 & 4.60 & 3.90 & 4.46 & 3.83 & 4.38 & 12.0 & 14.2 & 12.7 & 14.2 & 11.8 & 14.1 \\
\hline Mean & \multirow{2}{*}{\multicolumn{2}{|c|}{4.44}} & \multicolumn{2}{|c|}{4.28} & \multirow{2}{*}{\multicolumn{2}{|c|}{4.33}} & \multirow{2}{*}{\multicolumn{2}{|c|}{14.1}} & \multicolumn{2}{|c|}{14.1} & \multirow{2}{*}{\multicolumn{2}{|c|}{13.8}} \\
\hline \multirow[t]{2}{*}{ RMS } & & & \multicolumn{2}{|c|}{13.6} & & & & & \multicolumn{2}{|c|}{393} & & \\
\hline & \multicolumn{12}{|c|}{ Body lipid (g/kg body weight) ${ }^{4}$} \\
\hline R308 & 111 & 99 & 126 & 129 & 145 & 144 & 151 & 129 & 178 & 157 & 181 & 125 \\
\hline R788 & 112 & 101 & 132 & 111 & 151 & 130 & 157 & 126 & 232 & 111 & 154 & 136 \\
\hline Cobb & 128 & 109 & 130 & 108 & 162 & 134 & 177 & 110 & 161 & 124 & 227 & 151 \\
\hline Hybro & 106 & 90 & 125 & 129 & 152 & 143 & 189 & 106 & 194 & 123 & 157 & 144 \\
\hline Mean & \multirow{2}{*}{\multicolumn{2}{|c|}{107}} & & & & & & & & & & \\
\hline RMS & & & & & & & & & & & & \\
\hline
\end{tabular}

${ }^{1}$ Females; ${ }^{2}$ Males; ${ }^{3}$ Residual mean square.

${ }^{4}$ Body lipid content was calculated from gross energy (GE, measured using a bomb calorimeter) using the equation $\mathrm{L}=-0.8756+0.04754 * \mathrm{GE}$ (University of KwaZulu-Natal, unpublished). 
Although body weights and food intakes of broilers on each of the treatments were recorded each week, only the mean body weights at, and cumulative feed consumptions to six and 12 weeks, for each strain, sex and balanced protein level are presented here (Table 2) to indicate the extent to which these varied between birds on the various treatments. In all cases, males were heavier $(P<0.01)$, and consumed more feed $(P<0.01)$, than females.

Dietary protein content influenced growth rate and food intake, with numerically higher body weights and intakes being recorded on the highest feed protein level at both ages. Also presented in Table 2 are the mean body lipid contents of broilers sampled for carcass analysis at six and 12 weeks of age. Females had higher $(P<0.001)$ lipid contents than males (132 vs. 119 and 181 vs. $128 \mathrm{~g} / \mathrm{kg}$ at the two ages, respectively) and there was a linear increase $(P<0.01)$ in lipid content as dietary protein content declined at both ages.

The mean values presented in Table 2 demonstrate that the factors used, namely, strain, sex and feed protein content, produced widely different body weights and body compositions of birds on the different protein treatments.

Of the components of the body that were measured, only the weights of breast meat, thigh, drum and wing are given in the tables below. The mean weights of the remaining five components measured, namely, breast skin and bone, liver, gut and the remainder of the carcass are not presented in this paper, nor are the results of the chemical analyses of the carcasses other than the lipid content at six weeks. The entire dataset is available from the corresponding author on request.

In general, breast meat weight (Table 3$)$ was greater $(P<0.01)$ for males than females, on the high protein than on the medium or low protein feed $(P<0.01)$ and for the Cobb and Hybro strains from six weeks

Table 3 Mean breast meat weight (g), at weekly intervals, of females and males of four strains of broiler fed three levels of balanced protein to $84 \mathrm{~d}$ of age

\begin{tabular}{|c|c|c|c|c|c|c|c|c|c|c|c|c|c|}
\hline \multirow{3}{*}{$\begin{array}{l}\text { Age } \\
\text { (w) }\end{array}$} & \multicolumn{4}{|c|}{ Cobb } & \multicolumn{3}{|c|}{ Ross 308} & \multicolumn{3}{|c|}{ Ross 788} & \multicolumn{3}{|c|}{ Hybro } \\
\hline & \multirow[b]{2}{*}{$\mathrm{RMS}^{1}$} & \multicolumn{12}{|c|}{ Feed protein content } \\
\hline & & $\mathrm{H}^{2}$ & $M^{3}$ & $\mathrm{~L}^{4}$ & $\mathrm{H}$ & M & L & $\mathrm{H}$ & M & $\mathrm{L}$ & $\mathrm{H}$ & M & $\mathrm{L}$ \\
\hline & & \multicolumn{12}{|c|}{ Females } \\
\hline 1 & 3.3 & 13 & 13 & 10 & 15 & 13 & 12 & 15 & 14 & 12 & 16 & 14 & 11 \\
\hline 2 & 55 & 56 & 54 & 53 & 55 & 38 & 42 & 50 & 42 & 38 & 53 & 49 & 42 \\
\hline 3 & 351 & 124 & 96 & 93 & 108 & 103 & 81 & 110 & 97 & 75 & 106 & 102 & 97 \\
\hline 4 & 1012 & 196 & 212 & 205 & 217 & 182 & 187 & 220 & 151 & 167 & 236 & 194 & 196 \\
\hline 5 & 1629 & 370 & 336 & 317 & 273 & 268 & 235 & 296 & 290 & 259 & 355 & 284 & 302 \\
\hline 6 & 4705 & 477 & 360 & 461 & 410 & 430 & 343 & 407 & 348 & 333 & 367 & 424 & 338 \\
\hline 8 & 9551 & 729 & 730 & 660 & 640 & 567 & 575 & 592 & 561 & 510 & 687 & 703 & 594 \\
\hline 10 & 22597 & 888 & 919 & 830 & 655 & 830 & 782 & 729 & 759 & 745 & 929 & 921 & 818 \\
\hline \multirow[t]{2}{*}{12} & 33832 & 1234 & 1057 & 1046 & 859 & 901 & 893 & 905 & 850 & 884 & 1241 & 1051 & 1134 \\
\hline & & \multicolumn{12}{|c|}{ Males } \\
\hline 1 & 3.3 & 14 & 12 & 8.0 & 16 & 13 & 12 & 14 & 12 & 9.0 & 15 & 14 & 11 \\
\hline 2 & 55 & 50 & 53 & 43 & 55 & 47 & 28 & 57 & 50 & 36 & 51 & 50 & 43 \\
\hline 3 & 351 & 137 & 118 & 104 & 110 & 101 & 68 & 111 & 80 & 64 & 123 & 114 & 79 \\
\hline 4 & 1012 & 272 & 254 & 180 & 244 & 199 & 200 & 243 & 212 & 194 & 267 & 240 & 165 \\
\hline 5 & 1629 & 401 & 353 & 301 & 282 & 307 & 255 & 330 & 270 & 264 & 356 & 375 & 294 \\
\hline 6 & 4705 & 585 & 525 & 386 & 497 & 376 & 339 & 452 & 417 & 291 & 555 & 464 & 415 \\
\hline 8 & 9551 & 865 & 841 & 816 & 736 & 685 & 619 & 789 & 742 & 717 & 834 & 883 & 747 \\
\hline 10 & 22597 & 985 & 1068 & 1075 & 879 & 982 & 959 & 964 & 930 & 890 & 1175 & 1115 & 1106 \\
\hline 12 & 33832 & 1436 & 1212 & 1262 & 1335 & 1041 & 1162 & 1175 & 1074 & 1084 & 1506 & 1281 & 1376 \\
\hline
\end{tabular}

\footnotetext{
${ }^{1}$ Residual mean square; ${ }^{2}$ High protein; ${ }^{3}$ Medium protein; ${ }^{4}$ Low protein.
} 
( $P<0.01)$ onwards, the difference between these and the two Ross strains being $200 \mathrm{~g}$ at $12 \mathrm{w}$ (1239 vs. 1040 $\mathrm{g}$ ), which is the same order of magnitude as between males and females at that age. The Ross 788 strain generally exhibited the lowest breast meat yield at all ages.

Table 4 Main effects of strain, sex and feed protein content on the allometric coefficients (constant term and regression coefficient \pm standard error) relating weights (g) of breast meat, thigh, drum and wing to body protein weight, with goodness of fit $\left(\mathrm{R}^{2}\right)$. Where no differences exist between levels of a factor only one value is given for the constant term and/or regression coefficient

\begin{tabular}{|c|c|c|c|c|c|c|c|c|c|}
\hline \multirow{2}{*}{ Strain } & \multicolumn{4}{|c|}{ Constant Term } & \multicolumn{4}{|c|}{ Regression Coefficient } & \multirow{2}{*}{$\mathrm{R}^{2}$} \\
\hline & R308 & R788 & Cobb & Hybro & R308 & R788 & Cobb & Hybro & \\
\hline Breast & -2.530 & -2.530 & -2.434 & -2.434 & \multirow{2}{*}{\multicolumn{4}{|c|}{$1.415 \pm 0.009$}} & 969 \\
\hline & \multicolumn{4}{|c|}{ \pm 0.051} & & & & & \\
\hline \multirow{2}{*}{-day old ${ }^{1}$} & -1.439 & -1.439 & -1.614 & -1.439 & 1.230 & 1.230 & 1.277 & 1.252 & 99.3 \\
\hline & \multicolumn{4}{|c|}{ \pm 0.039} & \multicolumn{3}{|c|}{ \pm 0.007} & & \\
\hline \multirow[t]{2}{*}{ Thigh } & \multirow{2}{*}{\multicolumn{4}{|c|}{ \pm 0.026}} & 1.059 & & \pm 0.005 & 1.040 & 99.6 \\
\hline & & & & & 1050 & $\begin{array}{r} \pm 0.0 \\
1.039\end{array}$ & 1030 & 1025 & \\
\hline Drum & \multicolumn{4}{|c|}{ \pm 0.025} & \multicolumn{4}{|c|}{ \pm 0.005} & 99.6 \\
\hline Wing $^{2}$ & \multicolumn{4}{|c|}{$-1.400 \pm 0.016$} & \multicolumn{4}{|c|}{$0.984 \pm 0.003$} & 99.3 \\
\hline
\end{tabular}

Sex

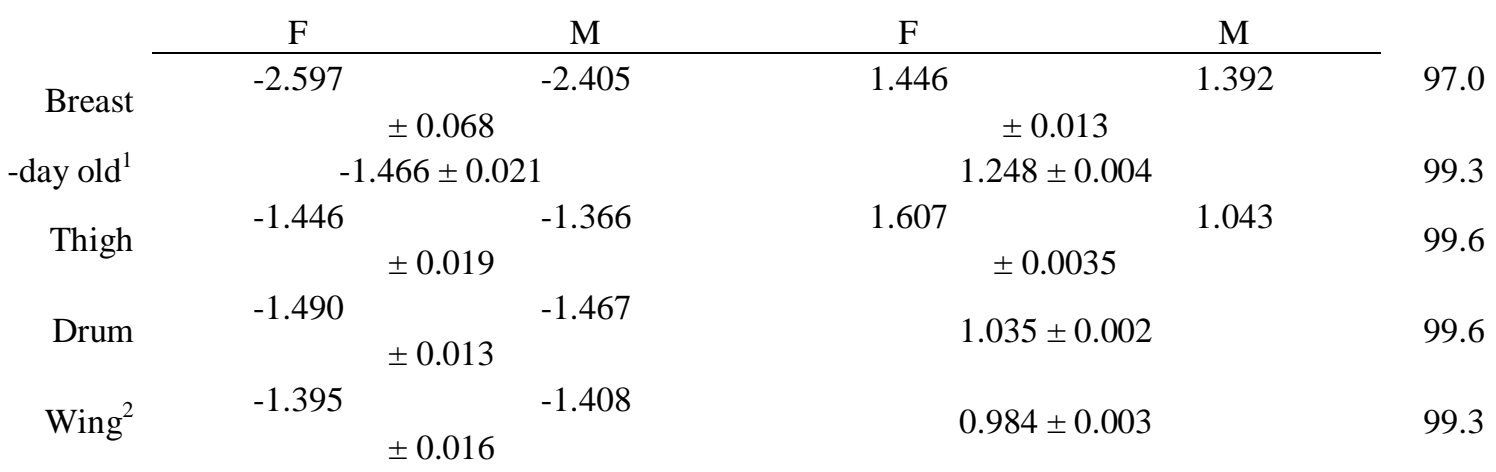

Feed Protein

\begin{tabular}{lrcrccrr} 
& HP & MP & LP & HP & MP & LP & \\
\cline { 2 - 6 } Breast & -1.388 & -1.431 & -1.632 & 1.231 & 1.237 & 1.266 & \\
& & \pm 0.037 & & & \pm 0.007 & & 99.3 \\
Thigh & -1.336 & -1.406 & -1.394 & 1.035 & 1.051 & 1.056 & \\
& & \pm 0.028 & & & \pm 0.003 & & \\
Drum & -1.473 & -1.498 & -1.450 & & 1.033 & & \\
& & \pm 0.017 & & & \pm 0.003 & & \\
Wing & -1.417 & -1.398 & 1.390 & & 0.984 & & \\
& & \pm 0.017 & & & \pm 0.003 & &
\end{tabular}

\footnotetext{
${ }^{1}$ Coefficients are for breast meat weight excluding dayold weights.
}

2 Coefficients are for wing weight excluding dayold weights.

Data for breast meat and body protein weight from each bird sampled were used to calculate allometric equations for each strain, sex and feed protein level, which were compared using simple linear regression with groups in Genstat (2002), the respective coefficients for the main effects of the three factors 
being presented in Table 4. Where no differences were apparent in either the constant term or regression coefficient the common value is presented, as with those between strains when the day-old weights are excluded from the regression, where only one constant term (-1.466) and regression coefficient (1.248) is necessary to describe breast meat weight in terms of body protein content in both sexes. Day-old breast weights were excluded from the allometric analysis because these values fell below the slope common to all later measurements thereby causing the slope to steepen and the goodness of fit to diminish as illustrated in Figure 1. Small differences in allometric coefficients between factors for breast meat were evident between the two Ross strains on the one hand, and the Cobb and Hybro strains on the other, where the constant terms were -2.53 and -2.43 respectively but with the regression coefficient being the same in all four strains (1.415). The three levels of dietary protein resulted in linear trends in both constant terms (decreasing from -1.388 on the highest to -1.632 on the lowest protein level) and regression coefficients, which increased from 1.231 to 1.266 .

Significant two-way interactions in the allometric coefficients for breast meat yield occurred between strain and sex (Table 5) with the two Ross strains having a higher constant term and lower slope, and the Cobb females showing a lower constant term $(-0.281 \pm 0.07)$ and steeper slope $(0.063 \pm 0.013)$ than the Cobb males, which were used as the reference strain. Hybro females exhibited a steeper slope $(+0.036 \pm$ 0.013) than Cobb males. The Ross strains thus had higher breast meat weights in the early stages of growth but with the Cobb strain overtaking this advantage at some stage before the end of the growing period. Interactions also occurred between strain and feed protein content (Table 6) where the Ross strains on the highest protein level (P1), for example, had higher constant terms $(0.204$ and 0.260$)$ and reduced regression coefficients ( -0.051 and -0.058 , respectively) than the Cobb strain on P1, and between feed protein level and sex (Table 7). An example of the latter interaction is that between males and females on the lowest protein level (P3), where females had a lower constant term $(-0.422 \pm 0.067)$ and a higher regression coefficient $(0.081 \pm 0.012)$. The three way interactions between strain, sex and dietary protein levels are given in Table 8. The constant terms for four of the combinations fed P3 were lower than the reference combination (Cobb males on P1) and the slopes for four of the combinations involving the two Ross strains were flatter and for some of the Cobb and Hybro strains, steeper, than the reference combination.

Table 5 Parameters for the significant two-way interactions between strain and sex over all dietary protein levels in breast meat (excluding day-old observations) and drum weight

\begin{tabular}{lcccr}
\hline \multicolumn{1}{c}{ Parameter } & estimate & SE & t (814) & t pr. \\
\hline Breast & & & & \\
Constant $^{1}$ & -1.508 & 0.049 & -31.0 & $<0.001$ \\
ln_BP $^{1}$ & 1.252 & 0.009 & 146 & $<0.001$ \\
R308M & 0.159 & 0.069 & 2.29 & 0.022 \\
R788M & 0.158 & 0.069 & 2.29 & 0.022 \\
Cobb F & -0.281 & 0.071 & -3.95 & $<0.001$ \\
ln_BP. R308 M & -0.044 & 0.012 & -3.63 & $<0.001$ \\
ln_BP. R788 M & -0.046 & 0.012 & -3.79 & $<0.001$ \\
ln_BP. Cobb F & 0.063 & 0.013 & 5.00 & $<0.001$ \\
ln_BP. Hybro F & 0.036 & 0.013 & 2.80 & 0.005 \\
Drum & & & & \\
Constant & -1.477 & 0.042 & -34.9 & $<0.001$ \\
ln_BP & 1.033 & 0.007 & 139 & $<0.001$ \\
ln_BP. R308F & 0.024 & 0.011 & 2.16 & 0.031 \\
\hline 1 & & & &
\end{tabular}

${ }^{1}$ Reference level is Cobb Male; ${ }^{2}$ Ross 308 Male. 
The mean thigh weights of broilers on the various treatments, at weekly intervals, are given in Table 9 . The weight referred to here, includes bone and skin and is the mean of the two thighs from each bird. At $84 \mathrm{~d}$ the mean thigh weights of the four strains over all protein levels were similar (352, 328, 313 and $335 \mathrm{~g}$ for Cobb, Ross 308 and 788 and Hybro, respectively), whereas the mean weight of male thighs (377 g) was $89 \mathrm{~g}$ heavier than those of females. Up to $42 \mathrm{~d}$ the mean thigh weight over all strains was directly related to feed protein content but thereafter thigh weight was heaviest on the low protein feed. This was not the case in each strain, however, the change-over being the result of the considerably higher thigh weights in the two Ross strains on the low protein feed, whereas the other two strains retained the direct relationship between dietary protein content and mean thigh weight. The main effect of strain on the allometric relationship between thigh weight and body protein weight (Table 5) resulted in significant differences in constant terms between strains but all having the same regression coefficient, i.e. the rate at which thigh weight increased with body protein content was the same in all strains, but the initial weight differed; this difference therefore being maintained throughout the growing period. Both the constant term and regression coefficient were the same for both sexes but, as with breast meat, a decrease in feed protein level caused the constant term to decrease linearly whilst the regression coefficient increased.

Table 6 Parameters for the significant two-way interactions between strain and feed protein levels over both sexes in breast meat and thigh weight

\begin{tabular}{lcccr}
\hline \multicolumn{1}{c}{ Parameter } & estimate & SE & t (806) & t pr. \\
\hline Breast & & & & \\
Constant & & & & \\
ln_BP $^{1}$ & -1.538 & 0.067 & -23.0 & $<0.001$ \\
R308 P1 & 1.264 & 0.012 & 108 & $<0.001$ \\
R788 P1 & 0.204 & 0.096 & 2.13 & 0.034 \\
Cobb P4 & 0.260 & 0.095 & 2.75 & 0.006 \\
ln_BP. R308 P1 & -0.249 & 0.092 & -2.72 & 0.007 \\
ln_BP. R308 P2 & -0.051 & 0.017 & -3.00 & 0.003 \\
ln_BP. R788 P1 & -0.036 & 0.017 & -2.17 & 0.030 \\
ln_BP. R788 P2 & -0.058 & 0.017 & -3.46 & $<0.001$ \\
ln_BP. Cobb P3 & -0.048 & 0.017 & -2.90 & 0.004 \\
Thigh & 0.041 & 0.016 & 2.53 & 0.011 \\
Constant & & & & \\
ln_BP & -1.324 & 0.056 & -23.8 & $<0.001$ \\
Cobb P2 & 1.035 & 0.010 & 106 & $<0.001$ \\
ln_BP. R308 P3 & -0.181 & 0.078 & -2.32 & 0.021 \\
ln_BP. Cobb P3 & 0.028 & 0.014 & 2.06 & 0.040 \\
ln_BP. Cobb P2 & 0.029 & 0.014 & 2.14 & 0.032 \\
\hline
\end{tabular}

${ }^{1}$ Reference level is Cobb on feed protein level 1 (P1).

There were no two-way interactions between strain and sex in the case of thigh weight, but feed protein level interacted with both strain (Table 7) and sex (Table 8). The interaction with strain occurred in one case only, with the regression coefficient for the Ross 788 fed the lowest feed protein level being $0.064 \pm$ 0.022 higher than all other combinations of strain and feed protein content. The interaction with sex was brought about also at the lower feed protein contents, with higher regression coefficients being exhibited by females on both protein level $3(0.030 \pm 0.018)$ and $4(0.049 \pm 0.018)$, and by males on protein level $4(0.044$ \pm 0.018). Some three-way interactions were evident, indicating that the Ross and Cobb strains differed in their response to low protein feeds, with Ross 788 females on the lowest protein level differing from other strain $\mathrm{x}$ sex combinations in both constant term and regression coefficient. 
The mean drum weights of broilers on the various treatments, at weekly intervals, are given in Table 10. The weight referred to here, includes bone and skin and is the mean of the two drums from each bird. At $84 \mathrm{~d}$ the mean drum weights of the four strains over all protein levels were similar (260, 263, 268 and $271 \mathrm{~g}$ for Cobb, Ross 308 and 788 and Hybro, respectively), whereas the mean weight of male drums (308 g) was $84 \mathrm{~g}$ heavier than those of females. Unlike with the thigh, there were no two-way interactions between strain and feed protein level in the case of the drum, and only one instance each in which strain and sex, and feed protein and sex, interacted (Tables 5 and 7, respectively). Cobb females on the high protein feed exhibited a lower regression coefficient $(-0.046, P<0.05)$ than Cobb males on the same protein level (Table 8), this being the only three-way interaction in the case of drum weights in this trial.

The mean wing weights of broilers on the various treatments, at weekly intervals, are given in Table 11. As with the thigh and drum weights reported, the weight referred to here, includes bone and skin and is the mean of the two wings from each bird. Only $8 \mathrm{~g}$ separated the mean wing weights at $84 \mathrm{~d}$ over both sexes between strains, the heaviest being those from the Hybro strain (204 g) and the lightest (196 g) from Ross 308. Conversely, $55 \mathrm{~g}$ separated the mean wing weights between males and females at $84 \mathrm{~d}$.

Table 7 Parameters for the significant two-way interactions between feed protein level and sex over all strains in breast meat, thigh, drum and wing weight

\begin{tabular}{|c|c|c|c|c|}
\hline Parameter & estimate & SE & t (818) & t pr. \\
\hline \multicolumn{5}{|l|}{ Breast } \\
\hline Constant $^{1}$ & -1.312 & 0.047 & -27.9 & $<0.001$ \\
\hline $\ln \_B P^{1}$ & 1.212 & 0.008 & 148 & $<0.001$ \\
\hline P1 F & -0.204 & 0.069 & -2.94 & 0.003 \\
\hline P3 F & -0.422 & 0.067 & -6.31 & $<0.001$ \\
\hline P3 M & -0.259 & 0.065 & -4.00 & $<0.001$ \\
\hline P2 F & -0.272 & 0.068 & -3.99 & $<0.001$ \\
\hline ln_BP. P1 F & 0.049 & 0.012 & 3.96 & $<0.001$ \\
\hline ln_BP. Р3 F & 0.081 & 0.012 & 6.79 & $<0.001$ \\
\hline ln_BP. P3 M & 0.035 & 0.011 & 3.07 & 0.002 \\
\hline ln_BP. P2 F & 0.060 & 0.012 & 4.93 & $<0.001$ \\
\hline \multicolumn{5}{|l|}{ Thigh } \\
\hline Constant & -1.307 & 0.038 & -34.2 & $<0.001$ \\
\hline ln_BP & 1.029 & 0.007 & 155 & $<0.001$ \\
\hline P3 F & -0.091 & 0.054 & -1.68 & 0.093 \\
\hline $\mathrm{P} 2 \mathrm{~F}$ & -0.153 & 0.055 & -2.76 & 0.006 \\
\hline ln_BP. P3 F & 0.028 & 0.010 & 2.93 & 0.003 \\
\hline ln_BP. P3 M & 0.026 & 0.009 & 2.85 & 0.004 \\
\hline ln_BP. P2 F & 0.035 & 0.010 & 3.52 & $<0.001$ \\
\hline \multicolumn{5}{|l|}{ Drum } \\
\hline Constant & -1.427 & 0.039 & -36.7 & $<0.001$ \\
\hline ln_BP & 1.028 & 0.007 & 152 & $<0.001$ \\
\hline $\mathrm{P} 2 \mathrm{~F}$ & -0.118 & 0.056 & -2.09 & 0.037 \\
\hline
\end{tabular}

${ }^{1}$ Reference level is male on feed protein level 1 (P1).

As with the day-old breast weights, the mean wing weights at dayold fell below the allometric slope common to all later weights, and so were excluded from the allometric analysis. The main effects of strain, sex and feed protein content (Table 4) had no effect on the slope of the allometric regression with body protein content, although the constant terms differed marginally between sexes and feed protein. No two- 
way interactions were found for mean wing weight, but there was a three-way interaction (Table 8), with males of the Hybro strain on feed protein 2 exhibiting a higher constant term $(0.29, P<0.01)$ and a lower slope $(-0.05, P<0.01)$ than the Cobb males on the highest protein level.

\section{Discussion}

The four strains, two sexes and three dietary protein levels used in the trial had the desired effect of producing a wide range of rates of growth of the body and of the weights of the physical and chemical components of the birds sampled. As with the previous trial (Danisman \& Gous, 2011) the body weights achieved exceeded the breed standards for all strains used. The major difference between the design of this and the previous trial, apart from the number of strains and dietary protein levels used, was that the birds in this trial were sampled to $84 \mathrm{~d}$ of age, this being twice the age of the birds at the termination of the previous trial. The allometric regressions are therefore measured over a far wider range of body protein contents than in the previous trial.

Table 8 Parameters for the significant three-way interactions between strain, sex and feed protein level in breast meat, thigh, drum and wing weight

\begin{tabular}{|c|c|c|c|c|}
\hline Parameter & estimate & SE & t (782) & t pr. \\
\hline \multicolumn{5}{|l|}{ Breast } \\
\hline Constant $^{1}$ & -1.432 & 0.084 & -17.0 & $<0.001$ \\
\hline $\ln \_\mathrm{BP}^{1}$ & 1.240 & 0.015 & 84.6 & $<0.001$ \\
\hline R788 F P3 & -0.250 & 0.120 & -2.07 & 0.038 \\
\hline Cobb F P3 & -0.498 & 0.118 & -4.22 & $<0.001$ \\
\hline Cobb M P3 & -0.254 & 0.115 & -2.20 & 0.028 \\
\hline Hybro F P3 & -0.236 & 0.120 & -1.97 & 0.049 \\
\hline ln_BP. R308 M P1 & -0.042 & 0.021 & -2.00 & 0.046 \\
\hline ln_BP. R308 M P2 & -0.043 & 0.021 & -2.09 & 0.037 \\
\hline ln_BP. R788 M P1 & -0.047 & 0.021 & -2.26 & 0.024 \\
\hline ln_BP. R788 M P2 & -0.041 & 0.021 & -2.01 & 0.045 \\
\hline ln_BP. Cobb F P1 & 0.054 & 0.022 & 2.50 & 0.013 \\
\hline ln_BP. Cobb F P3 & 0.099 & 0.021 & 4.73 & $<0.001$ \\
\hline ln_BP. Cobb F P2 & 0.057 & 0.022 & 2.64 & 0.008 \\
\hline ln_BP. Hybro F P1 & 0.046 & 0.023 & 2.02 & 0.044 \\
\hline ln_BP. Hybro F P3 & 0.050 & 0.021 & 2.34 & 0.020 \\
\hline \multicolumn{5}{|l|}{ Thigh } \\
\hline Constant & -1.316 & 0.077 & -17.2 & $<0.001$ \\
\hline ln_BP & 1.034 & 0.013 & 77.5 & $<0.001$ \\
\hline ln_BP. Cobb F P2 & 0.040 & 0.020 & 2.02 & 0.043 \\
\hline \multicolumn{5}{|l|}{ Drum } \\
\hline Constant & -1.518 & 0.075 & -20.2 & $<0.001$ \\
\hline ln_BP & 1.042 & 0.013 & 79.7 & $<0.001$ \\
\hline ln_BP. Cobb F P1 & -0.046 & 0.019 & -2.40 & 0.017 \\
\hline \multicolumn{5}{|l|}{ Wing } \\
\hline Constant & -1.502 & 0.077 & -19.6 & $<0.001$ \\
\hline ln_BP & 1.003 & 0.013 & 75.0 & $<0.001$ \\
\hline Hybro M P2 & 0.291 & 0.108 & 2.70 & 0.007 \\
\hline ln_BP. Hybro M P2 & -0.051 & 0.019 & -2.68 & 0.007 \\
\hline
\end{tabular}

\footnotetext{
${ }^{1}$ Reference level is Cobb male on feed protein level 1 (P1).
} 
As in the previous trial (Danisman \& Gous, 2011), and in spite of differences in growth rates and carcass composition between the strains and sexes used, breast meat weight was unaffected by these factors when expressed as a proportion of the body protein content of the broiler. And, as with the previous trial, differences in the constant term and regression coefficient describing this relationship were brought about by rearing the birds on different levels of dietary protein, with the constant terms decreasing and the slopes increasing as feed protein content decreased. It was suggested previously that this effect could be the result of increasing amounts of lipid being deposited in the breast muscle as feed protein content is reduced resulting in increasing breast weights at a given body protein weight. It is known that body lipid deposition increases as feed protein content declines (Gous et al., 1990). The same situation exists for the other parts analysed in this trial, with feed protein being the major factor influencing the slope of the allometric regressions with body protein content. This issue can only be resolved by measuring the amount of lipid that is deposited in each of the parts when birds are fed decreasing amounts of dietary protein: breast meat would be expected to retain a lower proportion of lipid than would the thigh, for example. Adjustments could then be made to the weights of the parts proportional to the amount of lipid that would be expected to be deposited when the bird is fed a given level of dietary protein at each stage of growth.

Table 9 Mean thigh weight (g), at weekly intervals, of females and males of four strains of broiler fed three levels of balanced protein to 12 weeks of age

\begin{tabular}{|c|c|c|c|c|c|c|c|c|c|c|c|c|c|}
\hline \multirow{3}{*}{$\begin{array}{l}\text { Age } \\
\text { (w) }\end{array}$} & \multirow{3}{*}{$\mathrm{RMS}^{1}$} & \multicolumn{3}{|c|}{ Cobb } & \multicolumn{3}{|c|}{ R308 } & \multicolumn{3}{|c|}{ R788 } & \multicolumn{3}{|c|}{ Hybro } \\
\hline & & \multicolumn{12}{|c|}{ Feed protein content } \\
\hline & & $\mathrm{H}^{2}$ & $\mathrm{M}^{3}$ & $\mathrm{~L}^{4}$ & $\mathrm{H}$ & $\mathrm{M}$ & L & $\mathrm{H}$ & M & $\mathrm{L}$ & $\mathrm{H}$ & M & $\mathrm{L}$ \\
\hline & & \multicolumn{12}{|c|}{ Females } \\
\hline 1 & 1.3 & 8.4 & 6.9 & 7.3 & 8.4 & 7.4 & 7.3 & 9.0 & 8.4 & 7.8 & 8.5 & 8.1 & 6.8 \\
\hline 2 & 11 & 25 & 25 & 17 & 25 & 20 & 22 & 24 & 20 & 20 & 23 & 22 & 19 \\
\hline 3 & 42 & 46 & 38 & 37 & 39 & 40 & 40 & 43 & 42 & 37 & 39 & 39 & 43 \\
\hline 4 & 117 & 79 & 77 & 81 & 79 & 73 & 74 & 81 & 61 & 73 & 76 & 71 & 74 \\
\hline 5 & 105 & 106 & 103 & 102 & 100 & 97 & 102 & 106 & 105 & 103 & 101 & 97 & 101 \\
\hline 6 & 605 & 150 & 85 & 153 & 152 & 141 & 118 & 141 & 125 & 126 & 119 & 129 & 116 \\
\hline 8 & 568 & 193 & 205 & 189 & 212 & 174 & 196 & 192 & 183 & 178 & 186 & 195 & 165 \\
\hline 10 & 1106 & 222 & 230 & 236 & 194 & 227 & 250 & 217 & 248 & 222 & 229 & 248 & 222 \\
\hline \multirow{2}{*}{12} & 2210 & 318 & 295 & 309 & 241 & 281 & 289 & 272 & 276 & 275 & 314 & 279 & 308 \\
\hline & & \multicolumn{12}{|c|}{ Males } \\
\hline 1 & 1.3 & 8.4 & 6.1 & 6.1 & 9.1 & 7.9 & 7.7 & 7.5 & 7.3 & 6.2 & 8.1 & 8.2 & 7.8 \\
\hline 2 & 11 & 22 & 23 & 21 & 25 & 22 & 16 & 24 & 22 & 21 & 21 & 21 & 20 \\
\hline 3 & 42 & 52 & 47 & 43 & 43 & 42 & 34 & 45 & 36 & 33 & 49 & 44 & 37 \\
\hline 4 & 117 & 96 & 89 & 75 & 97 & 72 & 83 & 87 & 81 & 82 & 88 & 90 & 70 \\
\hline 5 & 105 & 129 & 113 & 110 & 102 & 119 & 103 & 123 & 100 & 112 & 109 & 123 & 108 \\
\hline 6 & 605 & 120 & 153 & 132 & 185 & 139 & 144 & 153 & 155 & 126 & 170 & 144 & 152 \\
\hline 8 & 568 & 243 & 259 & 245 & 239 & 228 & 234 & 242 & 242 & 252 & 233 & 228 & 233 \\
\hline 10 & 1106 & 283 & 287 & 324 & 266 & 307 & 323 & 285 & 297 & 322 & 319 & 322 & 348 \\
\hline 12 & 2210 & 403 & 392 & 398 & 352 & 392 & 415 & 349 & 340 & 371 & 406 & 344 & 362 \\
\hline
\end{tabular}

${ }^{1}$ Residual mean square.

${ }^{2}$ High protein; ${ }^{3}$ Medium protein; ${ }^{4}$ Low protein.

As in the first trial reported on this subject (Danisman \& Gous, 2011) the day-old breast meat weights again fell below the allometric slope common to all subsequent weights when regressed against body protein weight (Figure 1), but in addition, the day-old wing weights also had to be removed from the analysis in order to produce a more accurate relationship between this part and body protein, which was not the case in 
the earlier trial. Halevy et al. (2006) and Noy \& Sklan (1998) have shown that breast meat weights at dayold are heavier when chicks have had access to food prior to being removed from the incubator, which suggests that the breast muscle may be used to supply nutrients to the body during this period. A study comparing the effects of early feeding with the conventional approach on the allometric relationships between body protein and the physical parts of the body at dayold might shed light on whether the breast and wing are being depleted of nutrients for other purposes during the last stages of incubation.

The allometric coefficients obtained in this trial for breast meat weights were comparable with those of the first trial in this series (Danisman \& Gous, 2011). For example, the constant terms and regression coefficients for breast meat, excluding day-old weights, for the first and second trials were -1.466 and -1.428 , and 1.248 and 1.236 respectively. The regression coefficients for the other three parts analysed were not as comparable: for thigh these were 1.325 and 1.036, for drum, 1.035 and 1.015, and for wing, 0.984 and 1.055 respectively. These differences are likely to be statistical rather than biological in nature, because of sampling and other experimental errors when collecting data of this sort. The results of these two trials as well as those from a third trial on this topic are to be combined to determine a more accurate estimate of the allometric relationships between these parts and body protein.

Table 10 Mean drum weights (g), at weekly intervals, of females and males of four strains of broiler fed three levels of balanced protein to 12 weeks of age

\begin{tabular}{|c|c|c|c|c|c|c|c|c|c|c|c|c|c|}
\hline \multirow{3}{*}{$\begin{array}{l}\text { Age } \\
\text { (w) }\end{array}$} & \multirow{3}{*}{$\mathrm{RMS}^{1}$} & \multicolumn{3}{|c|}{ Cobb } & \multicolumn{3}{|c|}{ R308 } & \multicolumn{3}{|c|}{ R788 } & \multicolumn{3}{|c|}{ Hybro } \\
\hline & & \multicolumn{12}{|c|}{ Feed protein content } \\
\hline & & $\mathrm{H}^{2}$ & $\mathrm{M}^{3}$ & $\mathrm{~L}^{4}$ & $\mathrm{H}$ & M & $\mathrm{L}$ & $\mathrm{H}$ & M & $\mathrm{L}$ & $\mathrm{H}$ & M & $\mathrm{L}$ \\
\hline & & \multicolumn{12}{|c|}{ Females } \\
\hline 1 & 0.7 & 7.0 & 6.4 & 5.6 & 6.8 & 6.5 & 6.6 & 7.7 & 7.3 & 6.7 & 7.2 & 7.3 & 6.4 \\
\hline 2 & 7.9 & 21 & 18 & 15 & 21 & 14 & 18 & 20 & 18 & 17 & 20 & 19 & 18 \\
\hline 3 & 27 & 40 & 33 & 31 & 36 & 37 & 34 & 39 & 38 & 32 & 35 & 34 & 36 \\
\hline 4 & 80 & 65 & 59 & 61 & 68 & 60 & 60 & 67 & 54 & 62 & 64 & 55 & 60 \\
\hline 5 & 79 & 91 & 84 & 81 & 86 & 86 & 83 & 89 & 90 & 88 & 83 & 81 & 82 \\
\hline 6 & 340 & 116 & 70 & 111 & 117 & 125 & 102 & 117 & 105 & 105 & 100 & 106 & 91 \\
\hline 8 & 374 & 147 & 156 & 154 & 160 & 146 & 163 & 154 & 160 & 154 & 149 & 156 & 139 \\
\hline 10 & 782 & 191 & 188 & 178 & 167 & 202 & 210 & 179 & 214 & 183 & 188 & 202 & 185 \\
\hline \multirow[t]{2}{*}{12} & 1012 & 215 & 219 & 205 & 203 & 225 & 238 & 221 & 237 & 226 & 221 & 240 & 237 \\
\hline & & \multicolumn{12}{|c|}{ Males } \\
\hline 1 & 0.7 & 6.8 & 5.5 & 5.4 & 8.0 & 6.5 & 6.7 & 6.7 & 6.4 & 5.7 & 6.8 & 7.0 & 6.2 \\
\hline 2 & 7.9 & 19 & 19 & 19 & 22 & 19 & 15 & 22 & 19 & 16 & 21 & 19 & 18 \\
\hline 3 & 27 & 46 & 40 & 40 & 38 & 40 & 30 & 42 & 32 & 29 & 44 & 39 & 32 \\
\hline 4 & 80 & 80 & 78 & 59 & 85 & 67 & 74 & 81 & 72 & 66 & 77 & 75 & 57 \\
\hline 5 & 79 & 106 & 94 & 89 & 99 & 98 & 91 & 108 & 88 & 96 & 98 & 104 & 94 \\
\hline 6 & 340 & 110 & 138 & 100 & 159 & 130 & 121 & 138 & 135 & 113 & 137 & 129 & 125 \\
\hline 8 & 374 & 220 & 209 & 195 & 222 & 206 & 203 & 223 & 219 & 228 & 198 & 197 & 205 \\
\hline 10 & 782 & 235 & 247 & 241 & 254 & 277 & 289 & 276 & 275 & 269 & 274 & 263 & 260 \\
\hline 12 & 1012 & 337 & 295 & 292 & 319 & 262 & 337 & 309 & 283 & 334 & 329 & 292 & 308 \\
\hline
\end{tabular}

\footnotetext{
${ }^{1}$ Residual mean square; ${ }^{2}$ High protein; ${ }^{3}$ Medium protein; ${ }^{4}$ Low protein.
} 

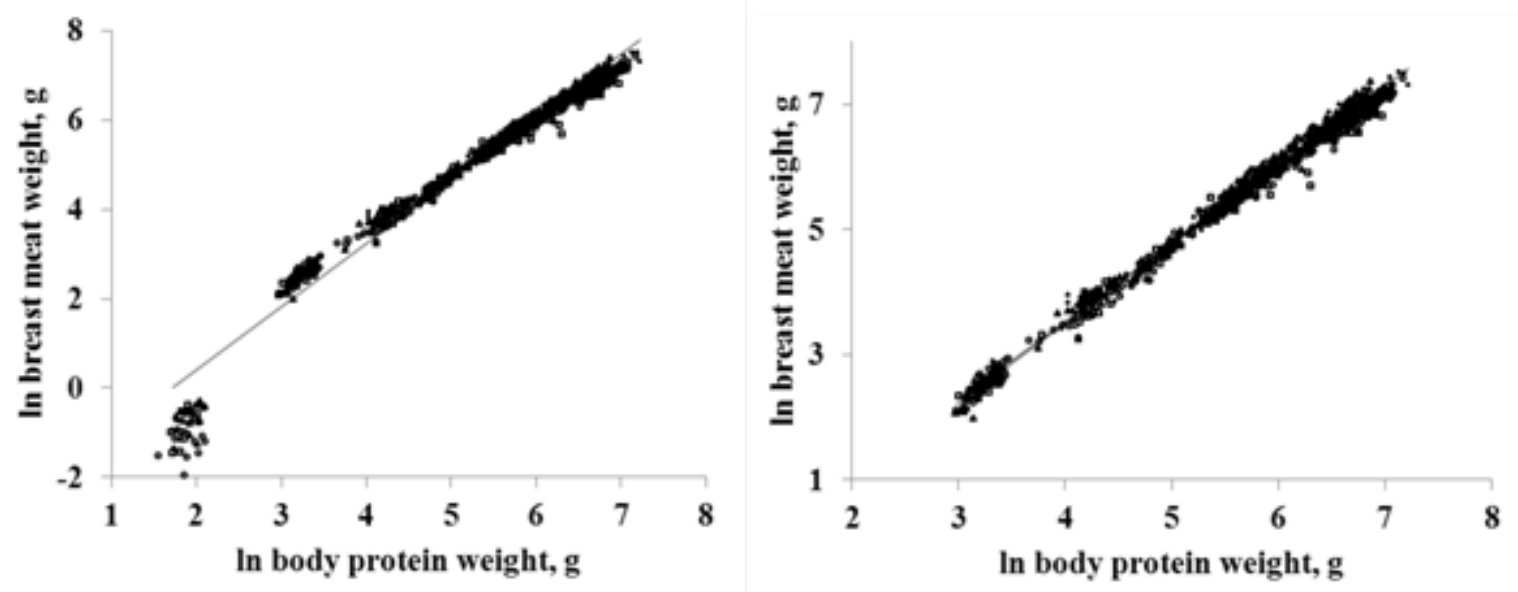

Figure 1 Allometric relationship between breast meat weight and body protein weight for the four strains used in the trial: Cobb, $\Delta$; Ross 308, - - ०; Ross 788, 口; Hybro, x. Graph on right excludes dayold weights.

Table 11 Mean wing weights (g), at weekly intervals, of females and males of four strains of broiler fed three levels of balanced protein to 12 weeks of age

\begin{tabular}{|c|c|c|c|c|c|c|c|c|c|c|c|c|c|}
\hline \multirow{3}{*}{$\begin{array}{c}\text { Age } \\
\text { (weeks) }\end{array}$} & \multirow{3}{*}{$\mathrm{RMS}^{1}$} & \multicolumn{3}{|c|}{ Cobb } & \multicolumn{3}{|c|}{ R308 } & \multicolumn{3}{|c|}{ R788 } & \multicolumn{3}{|c|}{ Hybro } \\
\hline & & \multicolumn{12}{|c|}{ Feed protein content } \\
\hline & & $\mathrm{H}^{2}$ & $\mathrm{M}^{3}$ & $\mathrm{~L}^{4}$ & $\mathrm{H}$ & $\mathrm{M}$ & $\mathrm{L}$ & $\mathrm{H}$ & M & $\mathrm{L}$ & $\mathrm{H}$ & M & $\mathrm{L}$ \\
\hline & & \multicolumn{12}{|c|}{ Females } \\
\hline 1 & 0.4 & 6.2 & 5.3 & 5.0 & 6.4 & 5.9 & 5.5 & 6.6 & 6.4 & 5.3 & 6.6 & 6.2 & 5.4 \\
\hline 2 & 5 & 18 & 17 & 13 & 18 & 15 & 17 & 16 & 16 & 16 & 19 & 17 & 15 \\
\hline 3 & 22 & 34 & 29 & 28 & 30 & 30 & 30 & 34 & 31 & 28 & 32 & 32 & 31 \\
\hline 4 & 55 & 53 & 56 & 52 & 56 & 53 & 51 & 56 & 43 & 49 & 57 & 56 & 52 \\
\hline 5 & 57 & 72 & 71 & 67 & 66 & 65 & 67 & 74 & 73 & 69 & 72 & 70 & 72 \\
\hline 6 & 199 & 98 & 60 & 97 & 97 & 85 & 79 & 95 & 85 & 83 & 79 & 89 & 79 \\
\hline 8 & 103 & 130 & 126 & 126 & 128 & 111 & 127 & 119 & 124 & 121 & 119 & 127 & 115 \\
\hline 10 & 237 & 151 & 142 & 139 & 133 & 145 & 153 & 142 & 152 & 145 & 148 & 154 & 161 \\
\hline \multirow[t]{2}{*}{12} & 448 & 184 & 172 & 171 & 142 & 168 & 179 & 165 & 179 & 185 & 184 & 177 & 176 \\
\hline & & \multicolumn{12}{|c|}{ Males } \\
\hline 1 & 0.4 & 5.9 & 5.1 & 4.7 & 6.0 & 5.6 & 5.7 & 5.5 & 5.6 & 4.8 & 6.2 & 6.3 & 5.5 \\
\hline 2 & 5 & 16 & 18 & 16 & 19 & 15 & 12 & 18 & 16 & 14 & 16 & 17 & 16 \\
\hline 3 & 22 & 39 & 35 & 30 & 32 & 31 & 25 & 34 & 29 & 26 & 38 & 35 & 30 \\
\hline 4 & 55 & 67 & 64 & 53 & 62 & 52 & 57 & 61 & 61 & 57 & 68 & 64 & 52 \\
\hline 5 & 57 & 68 & 75 & 73 & 73 & 78 & 70 & 78 & 79 & 74 & 77 & 90 & 75 \\
\hline 6 & 199 & 85 & 102 & 84 & 116 & 94 & 92 & 102 & 102 & 90 & 115 & 90 & 96 \\
\hline 8 & 103 & 169 & 168 & 136 & 155 & 143 & 149 & 157 & 162 & 155 & 153 & 154 & 156 \\
\hline 10 & 237 & 185 & 186 & 181 & 180 & 197 & 195 & 199 & 185 & 192 & 203 & 190 & 200 \\
\hline 12 & 448 & 252 & 215 & 221 & 228 & 231 & 234 & 223 & 212 & 240 & 239 & 234 & 216 \\
\hline
\end{tabular}

${ }^{1}$ Residual mean square; ${ }^{2}$ High protein; ${ }^{3}$ Medium protein; ${ }^{4}$ Low protein. 


\section{Conclusions}

The research reported here corroborates the results of the previous trial whose results suggested that, aside from the variable amounts of lipid that are deposited in the various body components resulting from differences in dietary protein content, the weights of these components may be accurately estimated from the body protein content of the broiler. It appears that day-old breast meat and wing weight is influenced by the nutritional status of the embryo which should thus be excluded from the allometric analysis. To improve the accuracy of prediction of component weights as influenced by strain, sex and dietary protein content the minimum and maximum amounts of lipid that can be deposited in these components by different broiler strains should be measured.

\section{Acknowledgements}

The authors acknowledge the financial contribution from the National Research Foundation and the Protein Research Foundation.

\section{References}

AOAC, 2003. Official Methods of Analysis. (17th ed.). Association of Official Analytical Chemists, Inc., Arlington, Washington, USA.

Aviagen, 2009. http://www.aviagen.com/ss/ross-708/ (accessed July 2010).

Cobb, 2007. http://www.cobbvantress.com/Products/ProductProfile/Cobb700_Sales_Brochure_ 2007.pdf (accessed July 2010).

Danisman, R. \& Gous, R.M., 2011. Effect of dietary protein on the allometric relationships between some carcass portions and body protein in three broiler strains. S. Afr. J. Anim. Sci. 41, 194-208.

Fisher, C. \& McNab, J.M., 1989. Techniques for determining the metabolizable energy content of poultry feeds. Cole, D.J.A. \& Haresign, W., Recent Developments in Poultry Nutrition, Butterworths. pp. 5469.

GenStat executable 2002. GenStat statistical software, Release 6.1 Lawes Agricultural Trust.

Gous, R.M., Pym, R.A.E., Mannion, P. \& Wu, J.X., 1996. An evaluation of the parameters of the Gompertz growth equation that describe the growth of eight strains of broiler. Australian Poultry Science Symposium, 8, 174 - 177, University of Sydney, Sydney, NSW.

Halevy, O., Yahav, S. \& Rozenboim, I., 2006. Enhancement of meat production by environmental manipulations in embryo and young broilers. Wrld Poult. Sci. J. 62, 485-497.

Hancock, C.E., Bradford, G.D., Emmans, G.C. \& Gous, R.M., 1995. The evaluation of the growth parameters of six breeds of commercial broiler chickens. Br. Poult. Sci. 36, 247-264.

Noy, Y. \& Sklan, D., 1998. Yolk utilisation in the newly hatched poultry. Br. Poult. Sci. 39, 446-451. 